\title{
Detecting genome-wide gene transcription profiles associated with high pollution burden in the critically endangered European eel
}

\author{
J.M. Pujolar ${ }^{\mathrm{a}, 1}$, M. Milan ${ }^{\mathrm{b}, 1}$, I.A.M. Marino ${ }^{\mathrm{a}}$, F. Capoccioni $^{\mathrm{c}}$, E. Ciccotti $^{\mathrm{c}}$, C. Belpaire $^{\mathrm{d}}$, \\ A. Covaci ${ }^{e}$, G. Malarvannan ${ }^{\text {e }}$, T. Patarnello ${ }^{b}$, L. Bargelloni ${ }^{b}$, L. Zane ${ }^{\mathrm{a}, *}$, G.E. Maes ${ }^{f}$ \\ a Department of Biology, University of Padova, I-35131 Padova, Italy \\ ${ }^{\mathrm{b}}$ Department of Comparative Biomedicine and Food Science, University of Padova, I-35020 Legnaro, Italy \\ c Department of Biology, Università Roma Tor Vergata, I-00133 Rome, Italy \\ ${ }^{\mathrm{d}}$ Research Institute for Nature and Forest, B-1560 Groenendaal-Hoeilaart, Belgium \\ e Toxicological Center, University of Antwerp, B-2610 Wilrijk, Belgium \\ ${ }^{\mathrm{f}}$ Laboratory of Biodiversity and Evolutionary Genomics, University of Leuven (KU Leuven), B-3000 Leuven, Belgium
}

\section{A R T I C L E I N F O}

\section{Article history:}

Received 28 November 2012

Received in revised form 28 January 2013

Accepted 15 February 2013

\section{Keywords:}

Anguilla anguilla

European eel

Microarrays

Pollution

Transcriptomics

\begin{abstract}
A B S T R A C T
The European eel illustrates an example of a critically endangered fish species strongly affected by human stressors throughout its life cycle, in which pollution is considered to be one of the factors responsible for the decline of the stock. The objective of our study was to better understand the transcriptional response of European eels chronically exposed to pollutants in their natural environment. A total of 42 pre-migrating (silver) female eels from lowly, highly and extremely polluted environments in Belgium and, for comparative purposes, a lowly polluted habitat in Italy were measured for polychlorinated biphenyls (PCBs), organochlorine pesticides (OCPs) and brominated flame retardants (BFRs). Multipollutant level of bioaccumulation was linked to their genome-wide gene transcription using an eel-specific array of 14,913 annotated cDNAs. Shared responses to pollutant exposure were observed when comparing the highly polluted site in Belgium with the relatively clean sites in Belgium and Italy. First, an altered pattern of transcription of genes was associated with detoxification, with a novel European eel CYP3A gene and gluthatione S-transferase transcriptionally up-regulated. Second, an altered pattern of transcription of genes associated with the oxidative phosphorylation pathway, with the following genes involved in the generation of ATP being transcriptionally down-regulated in individuals from the highly polluted site: NADH dehydrogenase, succinate dehydrogenase, ubiquinol-cytochrome c reductase, cytochrome coxidase and ATP synthase. Although we did not measure metabolism directly, seeing that the transcription level of many genes encoding enzymes involved in the mitochondrial respiratory chain and oxidative phosphorylation were down-regulated in the highly polluted site suggests that pollutants may have a significant effect on energy metabolism in these fish.
\end{abstract}

(ㄷ) 2013 Elsevier B.V. All rights reserved.

\section{Introduction}

Transcriptomic approaches enable one to further explore how natural populations respond to environmental change and to predict the impact of multiple exogenous influences including anthropogenic and oceanic climate stressors (Thomas and Klaper, 2004; Travers et al., 2007; Ungerer et al., 2008; Vandersteen, 2011). Such approaches have been used to explore transcriptomic responses in populations from polluted environments and have identified sets of candidate genes and loci that appear biologically important in response to pollution (Hoffmann and Willi, 2008; Bozinovic and Oleksiak, 2010). Understanding the effects of chronic

\footnotetext{
* Corresponding author. Tel.: +39 049 8276220; fax: +39 0498276209.

E-mail addresses: lorenzo.zane@unipd.it, lorenzo.zane@gmail.com (L. Zane).

1 Equal contribution.
}

exposure to environmental pollutants on the transcriptome is crucial to safeguard the adaptive potential of natural populations under heavy anthropogenic pressure (Cheung and Spielman, 2002; Hoffmann and Willi, 2008; Oleksiak, 2008). Since gene transcription is often altered as a result of toxicant exposure (Thomas et al., 2001; Hamadeh et al., 2002; Oleksiak, 2008), quantifying gene transcription levels during exposure to pollutants has the potential for early detection of compromised health (decreased fitness and survival), which has been used for improved conservation measures in several fish species, including rainbow trout Oncorhynchus mykiss (Hook et al., 2006), barbel Barbus graellsii (Quiros et al., 2007), the well-established model species Atlantic killifish Fundulus heteroclitus (Oleksiak, 2008) or the Mediterranean killifish Aphanius fasciatus (Kessabi et al., 2010).

While the effect of pollutants at the transcriptomic level has been well explored in natural populations of freshwater fish, less attention has been paid to diadromous fish species that complete 
their life cycle through ontogenic shifts between freshwater and marine environments. The study of diadromous species is particularly relevant because they represent a natural model to study the combined impact of continental anthropogenic and oceanic climate stressors. However, little is known about the transcriptional response to pollutants in species with a catadromous life cycle, such as the European eel Anguilla anguilla, a fish species in which a long-term stock decline has been reported across Europe, with indications that abundance of all stages of eel have decreased dramatically, possibly as much as 99 percent (ICES, 2011). Pollution is one of the factors that has been put forward to explain the decline of the eel stock together with other anthropogenic (overfishing, habitat degradation, man-introduced parasites and diseases) and environmental factors (oceanic and climatic changes) (Knights, 2003; Friedland et al., 2007; Bonhommeau et al., 2008; van den Thillart et al., 2009).

The European eels are highly adapted to oceanic gyral systems to complete their life cycle. After spawning in the Sargasso Sea, larvae are transported by the Gulf Stream to Europe and North Africa and metamorphose into glass eels upon reaching the continental shelf. Using tidal transport and their own swimming capacity, glass eels complete the migration into riverine, estuarine and coastal feeding habitats and grow up as yellow eels. After a highly variable feeding period of 5-15 years or more, yellow eels metamorphose into silver eels and migrate from their highly dispersed feeding regions back to the common spawning ground in the Sargasso Sea, where they die after spawning (van den Thillart et al., 2009). Philopatry to a single spawning ground and an extensive migration loop with great opportunity for mixing of individuals might explain the homogeneity in genetic composition between geographic areas across Europe, suggestive of a panmictic population (Dannewitz et al., 2005; Als et al., 2011). The observation of a smallscale pattern of genetic patchiness among intra-annual (arrival waves) samples does not conflict with the lack of large-scale geographic substructuring but it is most likely a consequence of a large variation in reproductive success (Pujolar et al., 2006, 2007, 2011a).

Our approach aims at better understanding the transcriptional response to pollutants in the European eel by means of a comparative analysis of gene transcription profiles (microarrays). Several experimental studies using real time-PCR have shown genetic responses to pollutants in the European eel (Aubry et al., 2007; Pierron et al., 2007, 2008, 2009; Maes et al., 2013). However, largescale transcriptomic approaches in eels have been limited to the study of osmoregulation (Kalujnaia et al., 2007) and a comparative gene transcription analysis between larvae of European and American eels (Bernatchez et al., 2011) using a 6000-probe microarray. Only recently a preliminary study has been conducted using an eel-specific microarray of 14,913 annotated cDNAs to compare two groups of silver eel males at two Italian sites with varying levels of pollution (Pujolar et al., 2012). In the present study, we extend the analysis to investigate the molecular responses to bioaccumulation levels in female silver eels across habitats with different levels of exposure to environmental pollutants. In order to identify both shared and unique responses, liver gene transcription was measured in two independent, polluted populations from Belgium (one highly-polluted and one extremely-polluted) and compared to two relatively clean populations from Belgium and Italy, respectively. A fundamental problem when comparing any two populations is to know whether differences are random or due to other more important factors, in this case, exposure to pollutants. Our approach using two geographically distant reference populations will allow us to identify differences due to pollution since shared differences in gene transcription can suggest shared mechanisms to cope with chronically polluted habitats.

\section{Material and methods}

\subsection{Sample collection}

Samples of European eel were collected during October 2009 in three separate locations of the river Scheldt basin in Belgium characterized by varying levels of environmental pollutants: (1) the lowly-polluted Wijmeers pond $\left(51^{\circ} 00^{\prime} \mathrm{N} ; 3^{\circ} 56^{\prime} \mathrm{E}\right)$ at Uitbergen, (2) the highly-polluted Hazewinkel pond $\left(51^{\circ} 03^{\prime} \mathrm{N} ; 4^{\circ} 23^{\prime} \mathrm{E}\right)$ at Willebroek, and (3) the extremely-polluted Dessel-Schoten canal at the locations of Sint-Job-in-'t-Goor $\left(51^{\circ} 18^{\prime} \mathrm{N} ; 4^{\circ} 34^{\prime} \mathrm{E}\right)$ and Schoten $\left(51^{\circ} 14^{\prime} \mathrm{N} ; 4^{\circ} 30^{\prime} \mathrm{E}\right)$. Eels were caught using electrofishing in Hazewinkel and using fyke nets in the rest of locations. All individuals collected were female adult silver eels at the pre-migrating stage, as determined by gonad development stage and eye diameter. Length $(\mathrm{L}, \mathrm{mm})$ and weight $(\mathrm{W}, \mathrm{g})$ was measured for each individual and Fulton's condition index was calculated as $\mathrm{CI}=\mathrm{W} / \mathrm{L}^{3}$. Biopsies of muscle and liver were collected for pollutants (stored at $-24^{\circ} \mathrm{C}$ ) and microarray (stored in RNALater) analyses, respectively.

In order to test the response to pollutants across a larger geographical scale, the analysis included female silver eels collected in the lowly-polluted Bolsena lake in Italy $\left(42^{\circ} 36^{\prime} \mathrm{N} ; 1^{\circ} 55^{\prime} \mathrm{E}\right)$ in October 2009, characterized by low residues of organochlorine pesticides and polychlorinated biphenyls, well below the Italian and European action levels (Pujolar et al., 2012).

\subsection{Pollutant measurements and analysis}

A total of 42 female silver eels ( 7 from Wijmeers, 8 from Hazewinkel and 27 from Dessel-Schoten) were measured for polychlorinated biphenyls (PCBs), organochlorine pesticides (OCPs) and brominated flame retardants (BFR), although it should be noted that other pollutants apart from the ones measured could be important. Samples were analyzed for 36 different PCB congeners, including the seven congeners considered as indicator PCBs (IUPAC No. 28, $52,101,118,138,153$ and 180). OCPs included hexachlorobenzene (HCB), pp-DDT and its major metabolite pp-DDE. BFRs included ten polybrominated diphenyl ethers (PBDEs) congeners (No. 28, 47, 49, $66,85,99,100,153,154$ and 183 ) and three hexabromocyclododecane (HBCDs) isomers.

An amount of $1 \mathrm{~g}$ eel muscle was weighed, homogenized with $\mathrm{Na}_{2} \mathrm{SO}_{4}$ and spiked with appropriate internal standards for the quantification of pollutants. Extraction in hot Soxhlet was performed during $2 \mathrm{~h}$ with hexane:acetone (3:1). Prior to clean-up, a fraction of the extract (typically between $1 / 8$ and $1 / 10$ ) was taken to determine the lipid content gravimetrically at $105^{\circ} \mathrm{C}$ for $12 \mathrm{~h}$. The remainder of the extract was subjected to clean-up on acidified silica. Details of the sample preparation procedure are described in Roosens et al. (2010).

Quantifications of PCBs, pp-DDE, pp-DDT and HCB were performed by gas chromatography-mass spectrometry (GC-MS, Agilent) with electron impact ionization (EI), PBDEs by GC-MS with electron-capture negative ionization (ECNI, Agilent) and HBCDs by liquid chromatography-mass spectrometry (LC-MS, Agilent) according to standard procedures (Roosens et al., 2010). The quality control procedures included the analysis of procedural blanks, duplicate samples and certified material SRM 1945 (whale blubber). This reference material has certified values for total lipids, PCBs, OCPs and PBDEs and indicative values for HBCDs. Obtained values for lipids and for all pollutants were deviating $<10 \%$ from the certified values and all samples were blank-corrected. For total lipids specifically, obtained values (mean \pm SD) were $74.4 \pm 3.7 \%$, compared to the reference values of $71.9 \pm 1.3 \%$. Recoveries of internal standards were all above $80 \%$, RSD $<10 \%$. Method quantification limits (LOQs) for individual pollutants were based on procedural 
blanks $(10 \times \mathrm{SD})$ and the amount of sample taken for analysis $(1 \mathrm{~g}$ eel muscle). LOQs ranged between 0.1 and $0.4 \mathrm{ng} / \mathrm{g}$ lipid wet weight.

Bioaccumulation of pollutants across locations was compared with an univariate ANOVA for each pollutant separately. A single and multivariate ANOVA (MANOVA) were conducted considering all pollutants (Sum 36 PCBs, HCB, pp-DDE, pp-DDT, Sum 10 PBDEs, Sum 3 HBCDs). All measurements were also compared by univariate ANOVA with those obtained at the Lake Bolsena in Italy, which were quantified using the same methodology (Pujolar et al., 2012). Significance for all statistical tests was taken as $p=0.05$. All statistical analyses were performed in STATISTICA v. 10.0 (Statsoft).

\subsection{Microarray analysis}

Gene transcription analysis was carried out in an eel-specific array constituted by 14,913 annotated cDNAs based on a large collection of existing and novel high-throughput transcriptomic sequences (Pujolar et al., 2012). Microarrays were synthesized in situ using the Agilent ink-jet technology with an $8 \times 15 \mathrm{~K}$ format ( 8 arrays in a single slide). Probe sequences and other details on the microarray platform can be found in the GEO database under accession number GPL15124. The analysis included a total of 38 individuals, all female silver eels, 30 from Belgium ( 7 from Wijmeers, 8 from Hazewinkel and 15 from Dessel-Schoten) and 8 from Italy (Bolsena). The individuals from Belgium were a subset of the individuals used in the analysis of pollutants, while different individuals from Bolsena were used for the contaminant and genetic work. For each individual, total RNA was extracted from a 20-30 mg piece of liver using the RNAeasy Mini Kit (Qiagen). RNA concentration was determined using a Nanodrop ND-1000 spectrophotometer (NanoDrop Technologies). RNA integrity and quality was estimated on an Agilent 2100 Bioanalyzer (Agilent Technologies). Minimum RNA Integrity Number (RIN) was 7.5.

Sample labeling and hybridization were carried out following the details in Pujolar et al. (2012). Hybridized slides were scanned at $5 \mu \mathrm{m}$ resolution using an Agilent DNA microarray scanner. Slides were scanned at two different sensitivity levels (XDR Hi $100 \%$ and XDR Lo 10\%) and the two linked images generated were analyzed together. Data were extracted and background subtracted using the standard procedure in Agilent Feature Extraction (FE) software v. 9.5.1. Hybridization success was evaluated using flag values, excluding those intensities not equal to 1 . Normalization procedures were performed using the R statistical software (http://www.r-project.org), with Spike-In control intensities used to identify the best normalization procedure. Quantile normalization always yielded better results than cyclic loess normalization and quantile-normalized data were used in all subsequent analysis. Normalized fluorescence data have been deposited in the GEO database (http://www.ncbi.nlm.nih.gov/geo) under accession number GSE41240.

A cluster analysis of the gene transcription profile of the individuals was conducted using the TMEV software (Saeed et al., 2003). Cluster analysis was applied to (a) all genes and (b) all differentially transcribed genes using a $0 \%$ false discovery rate (FDR). Data were visualized using Principal Component Analysis (PCA). Differentially transcribed genes across samples were identified using the statistical tests implemented in the program SAM (Significance Analysis of Microarrays) release 4.0 (Tusher et al., 2001). The two class unpaired test was used to compare pairs of samples and identify upand-down regulated genes differentially transcribed in response to pollution. A minimum of 1.5 fold change between groups was considered. The quantitative test was used to identify a correlation between gene transcription and individual measure of pollutants. We applied a 5\% FDR for multiple testing using the q-value method presented in Storey (2002).
Functional annotation analysis of differentially transcribed genes between locations was performed using the DAVID (Database for Annotation, Visualization and Integrated Discovery) web-server v6.7 (http://david.abcc.ncifcrf.gov). Prior to the analysis in DAVID, it was necessary to link differentially transcribed mRNA sequences with sequence identifiers that could be recognized in DAVID. To do so, a BLAST search was conducted for significant matches of the European eel transcripts directly against zebrafish Danio rerio Ensembl proteins using BLASTX. Danio rerio Ensembl Gene IDs were obtained from the corresponding Ensembl protein entries using the Biomart data mining tool in the Ensembl website (http://www.ensembl.org/biomart/). Gene functional analysis in DAVID was conducted defining the zebrafish IDs corresponding to differentially transcribed European eel transcripts as 'Gene list' and the zebrafish IDs corresponding to all genes represented in the array as 'Background'. Standard settings of gene count $=2$ and ease $=0.1$ were used. Additionally, a functional annotation clustering analysis was also conducted, in which differentially transcribed genes were grouped into functionally related sets of genes. Minimum overall enrichment score for each group based on the EASE scores of each term members was set to 1.3 , which is equivalent to the non-log scale of 0.05 .

\section{Results}

\subsection{Pollution analysis}

Average measures of length, weight, condition index and lipid content for all samples in the study are detailed in Table 1. No significant differences were found in condition index and all sites presented comparable values. The Dessel-Schoten location presented the lowest condition index $(\mathrm{CI}=1.52)$, but not significantly so $(p=0.189)$. No significant differences were found in lipid content across the three locations from Belgium ( $p=0.997)$, while eels from the Italian location of Bolsena showed a significantly higher lipid content $(p<0.001)$.

Comparison of bioaccumulation of pollutants pointed to a strong heterogeneity in pollution load across locations in Belgium (Table 1; Supplementary Figure 1 ). Highly significant differences were observed in measures of PCBs $(p<0.001)$, DDT $(p=0.004)$ and BFRs (PBDEs: $p=0.004$; HBCDs: $p=0.031$ ), with only pesticides HCB and DDE showing no significant differences. The Wijmeers location showed the lowest measures of contaminants in comparison with the other two Belgian locations, which were comparable to the values found for the lowly-polluted Italian lake of Bolsena (Pujolar et al., 2012). Concentration of all pollutants measured was consistently higher at Hazewinkel than in Wijmeers: about three times higher PCB levels, about five times higher DDT values and about 10 times higher BFR levels, suggestive of a highly polluted environment. The value of Sum 7 PCBs at Hazewinkel was two-fold higher than the value reported on eels collected from the urban tract of the heavily polluted river Tiber in Rome (167-372 ng/g ww; Miniero et al., 2011). Even higher values of contaminants were found in the Canal Dessel-Schoten, with concentrations of PCBs being 100 times higher in comparison with the lowly polluted Wijmeers location and 25 times higher than the highly polluted Hazewinkel location, which suggests that the Canal Dessel-Schoten is extremely polluted. Concentrations of BFRs were 20-50 times higher in Dessel-Schoten than in Wijmeers and 4-6 times higher than in Hazewinkel. With regard to pesticides, HCB concentrations were about 25-fold higher in Dessel-Schoten than in the two other locations, while differences in DDE and DDT values were not statistically significant. Both Hazewinkel (highly polluted) and Dessel-Schoten (extremely polluted) showed highly significant differences at all pollutant measurements in comparison with the low 
Table 1

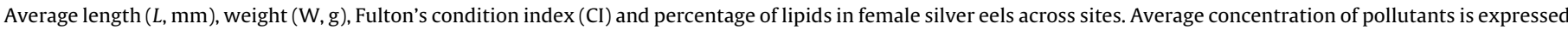

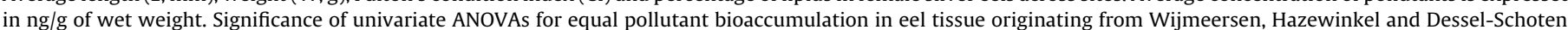
and, comparison with the Italian site of Bolsena: ${ }^{*} p<0.05,{ }^{* *} p<0.005,{ }^{* * *} p<0.001$, NS = Not Significant. SD = standard deviation.

\begin{tabular}{|c|c|c|c|c|c|c|c|c|c|c|}
\hline & \multicolumn{2}{|c|}{ Wijmeersen } & \multicolumn{2}{|c|}{ Hazewinkel } & \multicolumn{2}{|c|}{ Dessel-Schoten } & \multirow[t]{2}{*}{ Significance } & \multicolumn{2}{|l|}{ Bolsena } & \multirow[t]{2}{*}{ Significance } \\
\hline & Mean & SD & Mean & SD & Mean & SD & & Mean & SD & \\
\hline $\mathrm{L}$ & 670.29 & 53.26 & 510.63 & 138.32 & 704.29 & 74.58 & $* * *$ & 704.70 & 91.23 & $* * *$ \\
\hline W & 493.94 & 116.40 & 250.44 & 155.36 & 548.56 & 186.49 & $* * *$ & 688.56 & 278.42 & $* * *$ \\
\hline $\mathrm{CI}$ & 1.62 & 0.12 & 1.70 & 0.50 & 1.52 & 0.20 & NS & 1.89 & 0.18 & NS \\
\hline \% Lipids & 16.58 & 2.20 & 16.98 & 2.08 & 16.33 & 2.12 & NS & - & - & \\
\hline Sum 7 PCBs & 158.96 & 15.32 & 530.95 & 389.41 & $12,505.01$ & $10,079.00$ & $* * *$ & 37.63 & 43.00 & $* * *$ \\
\hline Sum 36 PCBs & 300.45 & 25.61 & 960.76 & 656.04 & $24,563.30$ & $19,998.20$ & $* * *$ & 73.63 & 86.99 & $* * *$ \\
\hline НСB & 1.54 & 0.71 & 2.01 & 1.41 & 35.14 & 60.13 & NS & 4.35 & 6.12 & NS \\
\hline pp-DDE & 285.99 & 32.90 & 315.7 & 281.74 & 482.64 & 398.72 & NS & 29.29 & 15.14 & $* * *$ \\
\hline pp-DDT & 4.95 & 3.92 & 29.54 & 25.21 & 65.81 & 52.44 & $* *$ & 5.45 & 5.15 & $* *$ \\
\hline Sum 10 PBDEs & 4.96 & 0.66 & 26.81 & 23.77 & 92.24 & 81.97 & $* *$ & 6.68 & 9.43 & $* *$ \\
\hline Sum 3 HBCDs & 3.35 & 2.00 & 40.23 & 31.92 & 245.9 & 316.05 & $*$ & 6.42 & 12.42 & $*$ \\
\hline
\end{tabular}

pollution Italian site of Bolsena except at HCB. Differences were particularly high between Bolsena and Dessel-Schoten with regard to PCBs, which were $>300$ times higher at Dessel-Schoten (Table 1). Finally, a multivariate ANOVA considering all contaminants (Sum 36 PCBs, HCB, pp-DDE, pp-DDT, Sum 10 PBDEs, Sum 3 HBCDs) showed significant differences when considering the three locations from Belgium $(p=0.043)$ and when adding the Italian location to the analysis $(p=0.022)$.

\subsection{Gene transcription analysis}

Visualization of gene transcription data by means of a Principal Component Analysis (PCA), using all genes, suggested three groupings (Fig. 1a), (i) one including all Italian (Bolsena) individuals, (ii) one including the individuals from the highly polluted Hazewinkel and (iii) one including the individuals from the two remaining locations, the lowly polluted Wijmeers and the extremely polluted Dessel-Schoten. The same three groupings were all the more apparent when only considering 850 differentially transcribed genes with a $0 \%$ FDR (Fig. 1b).

Differentially transcribed genes were identified using the twounpaired class Significance Analysis of Microarray (SAM) test on normalized data between pairs of locations using a 5\% FDR. A total of 2272 genes were differentially transcribed in the highly polluted Hazewinkel in comparison with the lowly polluted Wijmeers, 771 up-regulated and 1501 down-regulated. Similarly, a list of 2476 probes were differentially transcribed in Hazewinkel in comparison with the extremely polluted Dessel-Schoten, 1039 up-regulated and 1437 down-regulated. However, few genes were differentially transcribed in Dessel-Schoten in comparison with Wijmeers, 69 up-regulated and 19 down-regulated. When comparing the highly polluted Belgian location (Hazewinkel) with the lowly polluted Italian location (Bolsena), a total of 2796 genes were differentially transcribed, 978 up-regulated and 1818 down-regulated.

Enrichment analysis on genes that were transcriptionally upregulated in the highly polluted Hazewinkel site in comparison with the lowly polluted Wijmeers site using DAVID showed two over-represented KEGG pathways (Table 2). Firstly, metabolism of xenobiotics, including key detoxifications genes CYP3A65 (member of the cytochrome P450 superfamily) and glutathioneS-transferase class pi (part of the glutathione-S-transferase GST multigene superfamily). Secondly, ubiquitin-involved proteolysis including several subunits of the proteasome.

Enrichment analysis on genes that were transcriptionally downregulated in the highly polluted Hazewinkel site in comparison with the lowly polluted Wijmeers site showed a higher number of significantly enriched KEGG pathways, mostly related to energy metabolism (Table 3). The pathway with the highest significance and highest number of genes was oxidative phosphorylation, with a total of 43 transcriptionally down-regulated genes encoding key enzymes in the mitochondrial respiratory chain, namely NADH dehydrogenase, succinate dehydrogenase, ubiquinol-cytochrome c reductase, cytochrome c oxidase and ATP synthase (Supplementary Figure 2). Other enriched KEGG pathways were cardiac muscle contraction (8 genes), N-glycan biosynthesis ( 8 genes), aminoacyltRNA biosynthesis ( 6 genes) and lipic acid metabolism ( 3 genes).

Similar results were obtained when comparing the highly polluted Belgian location (Hazewinkel) with the lowly polluted Italian site (Bolsena). Enrichment analysis on genes that were transcriptionally up-regulated showed three KEGG pathways significantly over-represented in Hazewinkel (Supplementary Table 1): (i) Metabolism of xenobiotics, including CYP3A65 and glutathione-S-transferase class pi, (ii) ubiquitin-involved proteolysis (proteasome) and (iii) phosphatidylinositol-signaling pathway (8 genes). When considering transcriptionally down-regulated genes, six KEGG pathways were enriched (Supplementary Table 2): oxidative phosphorylation (62 genes), cardiac muscle contraction (20 genes), $\mathrm{N}$-glycan biosynthesis ( 7 genes), fructose and mannose metabolism (6 genes), citrate cycle (TCA cycle) (6 genes) and lipic acid metabolism (3 genes).

Surprisingly, very similar results were obtained when comparing the highly polluted Hazewinkel with the extremely polluted Dessel-Schoten location. Several detoxification genes related to metabolism of pollutants were transcriptionally up-regulated in Hazewinkel in comparison with Dessel-Schoten, including CYP3A and glutathione-S-transferase (Supplementary Table 3), while key genes in the mitochondrial respiratory chain and oxidative phosphorylation were transcriptionally under-regulated at Hazewinkel relative to Dessel-Schoten (Supplementary Table 4).

When correlating gene transcription and individual measures of pollutants in SAM, no significant associations were found when considering all Belgian samples, which might be due to the extreme

Table 2

KEGG pathways and genes transcriptionally up-regulated in the highly-polluted site of Hazewinkel in respect to the lowly-polluted site of Wijmeers.

\begin{tabular}{ll}
\hline KEGG pathway & Gene \\
\hline $\begin{array}{l}\text { Drug } \\
\text { metabolism/Xenobiotics }\end{array}$ & $\begin{array}{l}\text { cytochrome P450, family 3, subfamily A, } \\
\text { polypeptide 65 (CYP3A65) } \\
\text { glutathione-s-transferase pi } \\
\text { aldehyde dehydrogenase } 3 \text { family, member D1 } \\
\text { (ALDH3B1) }\end{array}$ \\
& proteasome subunit alpha type 6b \\
Proteasome & proteasome subunit alpha type 8 \\
& proteasome subunit alpha type 9a \\
& proteasome subunit alpha type 11 \\
\hline
\end{tabular}



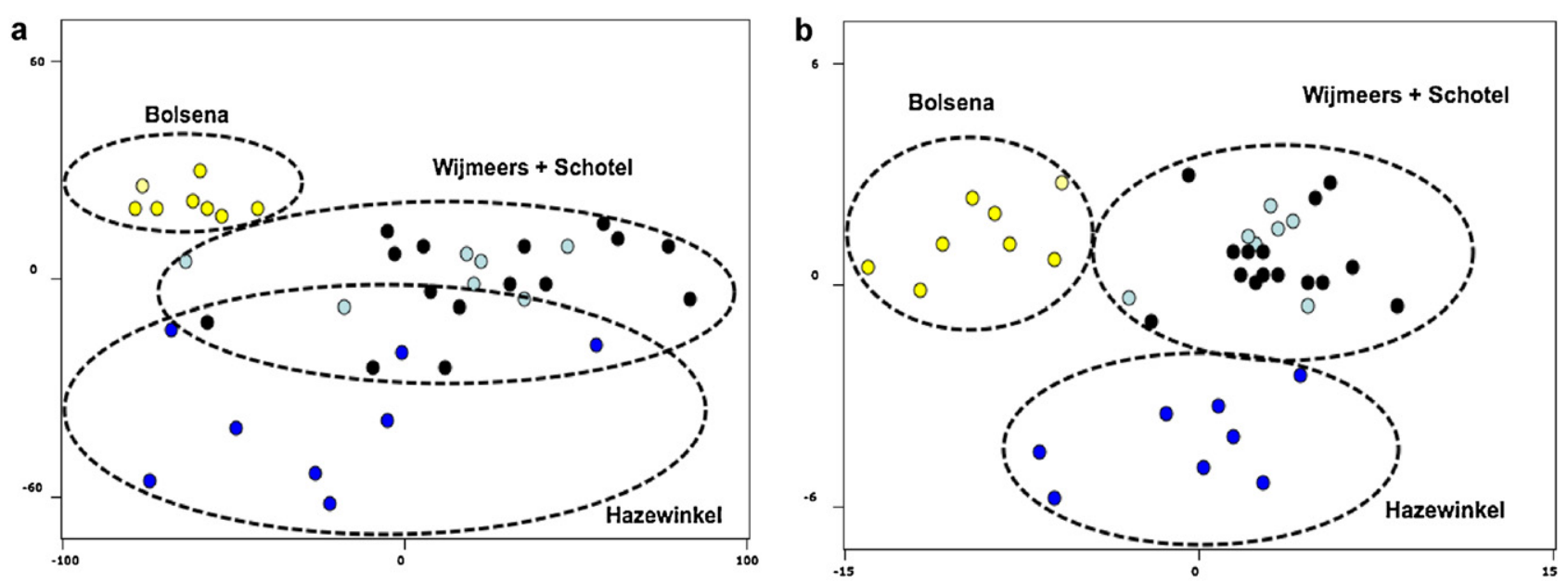

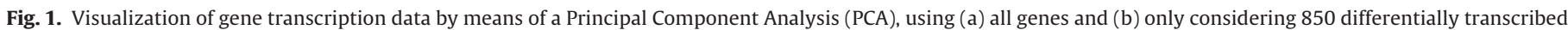
genes with a $0 \%$ false discovery rate.

level of pollution at Dessel-Schoten. However, when considering only Wijmeers and Hazewinkel, significant associations were found between gene transcription and individual measures of PCBs (275 positively correlated and 394 negatively correlated) and HBCDs (309 positively correlated and 663 negatively correlated) but not with HCB, pp-DDE, pp-DDT or PBDEs. Enrichment analysis of transcripts correlated with PCBs showed two enriched KEGG pathways: glycolisis/gluconeogenesis (4 genes positively correlated) and oxidative phosphorylation (35 genes negatively correlated). Enrichment analysis of transcripts positively correlated with HBCDs showed two enriched KEGG pathways: glycolysis/gluconeogenesis (5 genes) and insulin-signaling pathway (9 genes). Enrichment analysis of transcripts negatively correlated with HBCDs showed three enriched KEGG pathways: oxidative phosphorylation (33 genes), proteasome (10 genes) and N-glycan biosynthesis ( 7 genes).

\section{Discussion}

\subsection{Parallel transcriptional detoxification response to pollutants}

The goal of this study was to gain a snapshot of altered gene transcription in natural populations of European eel chronically exposed to environmental pollutants (PCBs, OCPs and BFRs) as compared to relatively clean reference populations. Shared differences in transcription of several genes related to detoxification were found when comparing the highly polluted site (Hazewinkel) with both the low polluted site in Belgium (Wijmeers) and the low polluted site in Italy (Bolsena), which suggests that the response is pollutant-related. Shared transcriptionally up-regulated genes included a novel European eel CYP3A gene shown to be orthologous to zebrafish Danio rerio CYP3A65 by phylogenetic analysis (Pujolar et al., 2012). CYP3A isozymes comprise the largest proportion of liver cytochrome P450 (CYP) enzymes, the main enzymes involved in the metabolism of xenobiotic substances such as drugs and environmental chemicals (Guengerich, 1991). CYP3A isozymes are involved in the first phase of the xenobiotic metabolism by means of introducing reactive or polar groups into the xenobiotics, thus modifying their chemical structure. Contaminants that have been shown to induce the transcription of CYP3A isozymes include PCBs (Schuetz et al., 1998), dioxins (Tseng et al., 2005) and PBDEs (Pacyniak et al., 2007). In addition, we also identified one transcriptionally upregulated gene involved in the second phase of the xenobiotic metabolism, glutathione S-transferase pi (GSTP1), previously described in many fish species including the
European eel (GenBank accession number AAS01601). Glutathione S-transferases (GSTs) catalyze the conjugation of the xenobiotic parent compound or its metabolites by covalently adding reduced glutathione. In contrast with phase I enzymes, an increase in GST activity as a response to xenobiotics does not seem to be universal, and a review of 43 laboratory and 39 field studies in fish only reported a significant GST activity increase in 33\% of the studies (Van der Oost et al., 2003).

Together with CYP3A and GSTP1, two more genes related to pollutants were transcriptionally up-regulated in the highly polluted Hazewinkel site. Firstly, aldehyde dehydrogenase ALDH3B1, which is part of a family of isozymes that may play a major role in the detoxification of aldehydes generated by alcohol metabolism and lipid peroxidation. Secondly, alcohol dehydrogenase ADH5, a member of a family of dehydrogenase enzymes that metabolizes a wide variety of alcohols that otherwise could be toxic such as ethanol or retinol.

Besides detoxification genes, several subunits of the proteasome were transcriptionally up-regulated. Proteasomes are protein complexes involved in the degradation of proteins that are damaged or no longer needed by proteolysis, turning them into amino acids that in turn can be used to synthesize new proteins. An increase in proteolysis is a protective mechanism of the cell to overcome the potentially toxic accumulation of damaged proteins (Grune et al., 1995). De Smet and Blust (2001) reported an increase in protein breakdown in acute cadmium-exposed common carp Cyprinus carpio as indicated by elevated protease activity in liver, gills and kidney. Similarly, Dorts et al. (2011) observed an increase of proteasome activity as a result of cadmium exposure in the European bullhead Cottus gobio using a proteomic approach. Finally, some genes in the phosphatidylinositol-signaling pathway were also transcriptionally up-regulated. This is a metabolic pathway that plays significant roles in many developmental processes as well as in cellular responses to environmental factors. In particular, phosphatidylinositol-3-kinases are a family of enzymes involved in key cellular functions such as cell growth, differentiation and survival.

\subsection{Depressed transcriptional detoxification at higher pollutant levels}

One surprising result in our study is the lack of transcription of detoxification genes in the individuals from the extremely polluted Dessel-Schoten site. Out of the four sites in our study, transcription of genes associated with detoxification such as CYP3A65 and 
Table 3

KEGG pathways and genes transcriptionally down-regulated in the highly-polluted site of Hazewinkel in respect to the lowly-polluted site of Wijmeers.

\begin{tabular}{|c|c|}
\hline KEGG pathway & Gene \\
\hline $\begin{array}{l}\text { Oxidative } \\
\text { phosphorylation }\end{array}$ & $\begin{array}{l}\text { ATP synthase, } \mathrm{H}+\text { transporting, mitochondrial F0 } \\
\text { complex, subunit b, subunit e, O subunit, alpha subunit } \\
1 \text {, delta subunit, gamma polypeptide } 1 \\
\text { ATP synthase, H+ transporting, subunit D, subunit F } \\
\text { ATP synthase, H+ transporting, lysosomal, V1 subunit } \\
\text { C, isoform } 1 \\
\text { COX17 cytochrome c oxidase } \\
\text { NADH dehydrogenase (ubiquinone) } 1 \text { alpha } \\
\text { subcomplex } 10,4,6,8,5 \\
\text { NADH dehydrogenase (ubiquinone) } 1 \text { beta subcomplex } \\
4,8,9 \\
\text { NADH dehydrogenase (ubiquinone) } 1 \text { alpha/beta } \\
\text { subcomplex } 1 \\
\text { NADH dehydrogenase (ubiquinone) Fe-S protein } 2,4,6 \\
\text { NADH-ubiquinone oxireductase chain } 2,3,5 \\
\text { cytochrome c oxidase subunit VIa polypeptide } 1 \text {, VIIa } 2 \\
\text { succinate dehydrogenase complex, subunit b, iron } \\
\text { sulfur } \\
\text { succinate dehydrogenase complex, subunit d, integral } \\
\text { membrane protein a and b } \\
\text { ubiquinol-cytochrome c reductase binding protein } \\
\text { ubiquinol-cytochrome c reductase core protein II } \\
\text { ubiquinol-cytochrome c reductase hinge protein } \\
\text { ubiquinol-cytochrome c reductase, complex III subunit } \\
\text { VII } \\
\text { ubiquinol-cytochrome c reductase Rieske iron-sulfur } \\
\text { polypeptide } 1 \\
\text { ubiquinol-cytochrome c reductase core protein II, } \\
\text { hinge protein, complex III subunit VII }\end{array}$ \\
\hline $\begin{array}{l}\text { Cardiac muscle } \\
\text { contraction }\end{array}$ & $\begin{array}{l}\text { ATPase, } \mathrm{Na}^{+} / \mathrm{K}^{+} \text {transporting, alpha } 1 \text { polypeptide } \\
\text { alpha-tropomyosin; tropomyosin } 1 \text { (alpha) } \\
\text { cytochrome c oxidase subunit VIa polypeptide } 1 \\
\text { cytochrome c oxidase subunit VIIa } 2 \\
\text { ubiquinol-cytochrome c reductase core protein II } \\
\text { ubiquinol-cytochrome c reductase hinge protein } \\
\text { ubiquinol-cytochrome c reductase, complex III subunit } \\
\text { VII }\end{array}$ \\
\hline $\begin{array}{l}\text { Aminoacyl-tRNA } \\
\text { biosynthesis }\end{array}$ & $\begin{array}{l}\text { arginyl-tRNA synthetase } 2 \\
\text { isoleucyl-tRNA synthetase } \\
\text { seryl-tRNA synthetase }\end{array}$ \\
\hline $\begin{array}{l}\mathrm{N}-\text { Glycan } \\
\text { biosynthesis }\end{array}$ & $\begin{array}{l}\text { aspargine-linked glycosylation } 3 \\
\text { aspargine-linked glycosylation } 10 \\
\text { defender against cell death } 1 \\
\text { dolichyl-phosphate mannosyltransferase polypeptide } \\
1 \text { and } 3 \\
\text { ribophorin } 1 \\
\text { integral membrane protein } 1\end{array}$ \\
\hline $\begin{array}{l}\text { Lipoic acid } \\
\text { metabolism }\end{array}$ & $\begin{array}{l}\text { Lip A (2.8.1.8) } \\
\text { Lip B (23.1.181) } \\
\text { Lip T1 }\end{array}$ \\
\hline
\end{tabular}

glutathione S-transferase was only altered in the individuals from the highly polluted Hazewinkel site. With regard to transcription of detoxification genes, the individuals from Dessel-Schoten behaved like the individuals from the lowly-polluted Wijmeers site, which explains why they clustered together in the PCA analysis. This might suggest a level of pollution so high at Dessel-Schoten that detoxification might no longer take place.

Our findings confirm the result from the recent study of Maes et al. (2013) on eels from three highly polluted river basins in Belgium using a Real-Time PCR approach, which showed a dysfunctional transcription of detoxification genes at higher pollutant levels. The authors suggested that transcription levels only increase linearly at low pollution levels and in healthy individuals and that the transcription of detoxification genes no longer occurs after a given threshold of pollutant exposure. The exposure to extreme levels of pollution may activate a protective mechanism against over-transcription of detoxification genes, such as CYP1A1, given that high activity may be deleterious since they can generate mutagenic metabolites and oxidative stress, and that it might be advantageous to tightly control their transcription (Barouki and Morel, 2001; Marohn et al., 2008; Oleksiak, 2008; Kessabi et al., 2010).

It is interesting to note that although eels in our study were from environments with drastically different pollution levels (lowly, highly and extremely polluted), condition index and lipid contents were similar across locations. Individuals from Dessel-Schoten presented a slightly lower condition index, but not statistically so. Similarly, re-examination of data in Pujolar et al. (2012) showed no differences in condition index between male silver eels from the lowly polluted lake Bolsena $(\mathrm{CI}=1.64 \pm 0.10)$ and the highly polluted river Tiber $(\mathrm{CI}=1.98 \pm 0.26)$. The condition index tended to be higher, but not significantly so, in the latter site $(p=0.103)$. This is in agreement with the notion that while lipophilic contaminants accumulate during the continental life phase of eels, the adverse effects of those contaminants are mainly triggered when adults migrate back to the Sargasso Sea for reproduction. Migrating eels totally depend on their fat stores to fuel migration and gonad development. With fat consumption, internal concentrations of lipophilic pollutants rise, increasing the risk of toxic effects (Palstra et al., 2006), which in turn can compromise migration and/or reproduction.

\subsection{Parallel decreased transcription of genes involved in the oxidative phosphorylation pathway}

Besides an altered shared transcription of genes associated with detoxification, a consistent difference in gene transcription of genes associated with energy metabolism was also observed. Many genes encoding enzymes in the mitochondrial respiratory chain and oxidative phosphorylation were transcriptionally downregulated in samples from the highly-polluted Hazewinkel site in comparison with both the low polluted site in Belgium (Wijmeers) and the low polluted site in Italy (Bolsena). Those included key genes encoding proteins involved in the generation of ATP: NADH dehydrogenase, succinate dehydrogenase, ubiquinol-cytochrome $c$ reductase, cytochrome $c$ oxidase and ATP synthase. Besides oxidative phosphorylation, other enriched metabolic pathways included lipoic acid metabolism, tRNA synthesis, glycon metabolism and gluconeogenesis among others. In agreement with our study, the experimental studies of Pierron et al. (2007) documented a decrease in transcription of genes involved in the respiratory chain in response to cadmium exposure and hypoxia in the gills of glass eels. Importantly, the genes involved in the oxidative phosphorylation pathway that were transcriptionally down-regulated in our study conducted on European eel females coincide with a previous study comparing European eel males from two Italian sites with varying levels of contaminants (Pujolar et al., 2012). NADH dehydrogenase, succinate dehydrogenase, ubiquinol-cytochrome c reductase, cytochrome $c$ oxidase and ATP synthase were all transcriptionally down-regulated in males from the highly polluted river Tiber in comparison with the relatively clean lake of Bolsena. This points to a consistent effect of pollutants on gene transcription across sexes, as the same response has been observed in both males and females.

The transcriptional differences observed indicate that differences in gene production activities are possible, but until protein amounts and activities are measured, speculative. However, the following discussion is based on the assumption that transcriptional differences are seen as functional differences. Seeing that key genes 
involved in the oxidative phosphorylation pathway were transcriptionally down-regulated in individuals with high pollution burden suggests that pollutants may have a significant effect on energy metabolism in these fish, possibly resulting in a low energetic status of the individuals. Although we did not measure metabolism directly, the suggested genome-wide low energetic status of premigrating eels from polluted areas points to a poor quality of spawners that could jeopardize spawning migration and reproduction in the Sargasso Sea. At present, there is increasing awareness that spawner quality might be directly or indirectly responsible for the decline of the European eel stocks. Spawner quality may be seriously impaired by pollution, diseases and parasites, with levels of pollution so high in some countries that immediate actions had to be taken and fisheries were closed as a measure to protect human health (ICES, 2011). Due to their particular ecological (benthic feeding) and physiological (high fat content) traits, eels are particularly sensitive to the bioaccumulation of lipophilic contaminants (Belpaire and Goemans, 2007). Different kinds of chemical compounds such as polychlorinated biphenyls (PCBs), pesticides and toxic metals have a serious impact on the health of eels (Robinet and Fenteun, 2002; Maes et al., 2005; Geerarts and Belpaire, 2010). A high contaminant burden could also impair normal reproduction or affect larval development, since lipids and lipophilic contaminants are mostly mobilized toward the gonads during the spawning migration (Palstra et al., 2006). This is in agreement with the recent genetic study of Pujolar et al. (2011b), in which the observation of a stable genetically effective population size suggests that the eel crash was not due to low numbers but poor quality of spawners. Due to the detrimental effect of pollutants on fitness and fecundity, the spawning stock may fail to produce a sufficient number of good quality eggs, leading to a decline in the recruitment of the stock while not yet impacting the effective population size of the European eel.

\section{Acknowledgments}

This work has been supported by Padova University grants to LZ (CPDA085158/08 and CPDR123580/12). AC and GM acknowledge financial support from the University of Antwerp. GEM acknowledges a postdoctoral fellowship from the Scientific Research Foundation of Flanders (FWO-Vlaanderen).

\section{Appendix A. Supplementary data}

Supplementary data associated with this article can be found, in the online version, at doi:10.1016/j.aquatox.2013.02.012.

\section{References}

Als, T.D., Hansen, M.M., Maes, G.E., Castonguay, M., Riemann, L., Aarestrup, K., Munk, P., Sparholt, H., Hanel, R., Bernatchez, L., 2011. All roads lead to home: panmixia of European eel in the Sargasso Sea. Molecular Ecology 20,1333-1346.

Aubry, E., Cagnon, C., Lalanne, Y., Mouches, C., 2007. Assessment of young yellow European eel Anguilla anguilla exposure to a CYP1A1 inducer by the quantification of increase in hepatic CYP1A1 mRNA using real-time RT-PCR. Journal of Fish Biology 71, 470-477.

Barouki, R., Morel, Y., 2001. Repression of cytochrome P450 1A1 gene expression by oxidative stress: mechanisms and biological implications. Biochemical Pharmacology 61, 511-516.

Belpaire, C., Goemans, G., 2007. Eels: contaminant cocktails pinpointing environmental pollution. ICES Journal of Marine Science 64, 1423-1436.

Bernatchez, L., St-Cyr, J., Normandeau, E., Maes, G.E., Als, T.D., Kalujmaia, S., Cramb, G., Castonguay, M., Hansen, M.M., 2011. Differential timing of gene expression regulation between leptocephali of the two Anguilla eel species in the Sargasso Sea. Ecology and Evolution 1, 459-467.

Bonhommeau, S., Chassot, E., Rivot, E., 2008. Fluctuations in European eel (Anguilla anguilla) recruitment resulting from environmental changes in the Sargasso Sea. Fisheries Oceanography 17, 32-44.

Bozinovic, G., Oleksiak, M.F., 2010. Genomic approaches with natural fish populations from polluted environments. Environmental Toxicology and Chemistry 30 , 283-289.
Cheung, V.G., Spielman, R.S., 2002. The genetics of variation in gene expression. Nature Genetics 32, 522-525.

Dannewitz, J., Maes, G.E., Johansson, L., Wickstrom, H., Volckaert, F.A.M., Jarvi, T. 2005. Panmixia in the European eel: a matter of time. Proceedings of the Royal Society of London Series B: Biological Sciences 272, 1129-1137.

De Smet, H., Blust, R., 2001. Stress responses and changes in protein metabolism in carp Cyprinus carpio during cadmium exposure. Ecotoxicology and Environment Safety $48,255-262$.

Dorts, J., Kestemont, P., Dieu, M., Raes, M., Silvestre, F., 2011. Proteomic response to sublethal cadmium exposure in a sentinel fish species, Cottus gobio. Journal of Proteome Research 10, 470-478.

Friedland, K.D., Miller, M.I., Knights, B., 2007. Oceanic changes in the Sargasso Sea and declines in recruitment of the European eel. ICES Journal of Marine Science 64, 519-530.

Geeraerts, G., Belpaire, C., 2010. A review of the effects of contaminants on European eel. Ecotoxicology 19, 239-266.

Grune, T., Reinheckel, T., Joshi, M., Davies, K.J., 1995. Proteolysis in cultured liver epithelial cells during oxidative stress. Role of the multicatalytic proteinase complex, proteasome. Journal of Biological Chemistry 270, 2344-2351.

Guengerich, F.P., 1991. Reactions and significance of cytochrome P450 enzymes. Journal of Biological Chemistry 266, 10019-10022.

Hamadeh, H.K., Bushel, P.R., Jayadev, S., Martin, K., DiSorbo, O., Sieber, S., Bennett, L., Tannant, R., Stoll, R., Barrett, J.C., Blanchard, K., Paules, R.S., Afshari, C.A., 2002. Gene expression analysis reveals chemical-specific profiles. Toxicological Sciences 67, 219-231.

Hoffmann, A.A., Willi, Y., 2008. Detecting genetic responses to environmental change. Nature Reviews Genetics 9, 421-432.

Hook, S.E., Skillman, A.D., Small, J.A., Schultz, L.R., 2006. Dose-response relationships in gene expression profiles in rainbow trout Oncorhynchus mykiss, exposed to ethynylestradiol. Marine Environment Research 62, 5151-5155.

ICES, 2011. Report of the Joint EIFAAC/ICES Working Group on Eels (WGEEL), 5-9 September 2011, Lisbon, Portugal. ICES CM 2011/ACOM:18. International Council for the Exploration of the Seas, Copenhagen.

Kalujnaia, S., McWilliam, I.S., Zaguinalko, V.A., Feilen, A.L., Nicholson, J., Hazon, N., Cutler, C.P., Cramb, G., 2007. Transcriptomic approach to the study of osmoregulation in the European eel Anguilla anguilla. Physiological Genomics 31, 385-401.

Kessabi, K., Navarro, A., Casado, M., Said, K., Messaoudi, I., Pina, B., 2010. Evaluation of environmental impact on natural populations of the Mediterranean killifish Aphanius fasciatus by quantitative RNA biomarkers. Marine Environment Research 70, 327-333.

Knights, B., 2003. A review of the possible impacts of long-term oceanic and climatic changes and fishing mortality on recruitment of anguillid eels of the Northern hemisphere. Science of the Total Environment 310, 237-244.

Maes, G.E., Raeymaekers, J.A.M., Pampoulie, C., Seynaeve, A., Goemans, G., Belpaire, C., Volckaert, F.A.M., 2005. The catadromous European eel Anguilla anguilla as a model for freshwater evolutionary ecotoxicology: relationship between heavy metal bioaccumulation, condition and genetic variability. Aquatic Toxicology 73, 99-114.

Maes, G.E., Raeymaekers, J.A.M., Hellemans, B., Geeraerts, C., Parmentier, K., De Temmerman, L., Volckaert, F.A.M., Belpaire, C., 2013. Gene transcription reflects poor health status of resident European eel chronically exposed to environmental pollutants. Aquatic Toxicology 126, 242-255.

Marohn, L., Rehbein, H., Kundiger, R., Hanel, R., 2008. The suitabilty of cytochromeP4501A1 as a biomarker for PCB contamination in European eel (Anguilla anguilla). Journal of Biotechnology 136, 135-139.

Miniero, R., Guandalini, E., Dellatte, E., Iacovella, N., Abate, V., De Luca, S., Iamiceli, A.L., di Domenico, A., De Felip, E., 2011. Persistent organic pollutants (POPs) in fish collected from the urban tract of the river Tiber in Rome (Italy). Annali dell Istituto Superiore di Sanita 47, 310-315.

Oleksiak, M.F., 2008. Changes in gene expression due to chronic exposure to environmental pollutants. Aquatic Toxicology 90, 161-171.

Pacyniak, E.K., Cheng, X., Cunningham, M.L., Crofton, K., Klaassen, C.D., Guo, G.L., 2007. The flame retardants, polybrominated diphenyl ethers, are pregnane $X$ receptor activators. Toxicological Sciences 97, 94-102.

Palstra, A.P., Van Ginneken, V.J.T., Murk, A.J., van den Thillart, G., 2006. Are dioxin-like contaminants responsible for the eel Anguilla anguilla drama? Naturwissenschaften 93, 145-148.

Pierron, F., Baudrimont, M., Gonzalez, P., Bourdineaud, J.P., Elie, P., Massabuau, J.C., 2007. Common pattern of gene expression in response to hypoxia or cadmium in the gills of the European glass eel (Anguilla anguilla). Environmental Science and Technology 51, 3005-3011.

Pierron, F., Baudrimont, M., Dufour, S., Elie, P., Bossy, A., Baloche, S., Mesmer-Dudons, N., Gonzalez, P., Bourdineaud, J.P., Massabuau, J.C., 2008. How cadmium could compromise the completion of the European eel's reproductive migration. Environmental Science and Technology 52, 4607-4612.

Pierron, F., Baudrimont, M., Dufour, S., Elie, P., Bossy, A., Lucia, M., Massabuau, J.C., 2009. Ovarian gene transcription and effect of cadmium pre-exposure during artificial sexual maturation of the European eel (Anguilla anguilla). Biometals 22, 985-994.

Pujolar, J.M., Maes, G.E., Volckaert, F.A.M., 2006. Genetic patchiness among recruits of the European eel Anguilla anguilla. Marine Ecology Progress Series 307, 209-217.

Pujolar, J.M., Maes, G.E., Volckaert, F.A.M., 2007. Genetic and morphometric heterogeneity among recruits of the European eel, Anguilla anguilla. Bulletin of Marine Science 81, 297-308.

Pujolar, J.M., Bevacqua, D., Andrello, M., Capoccioni, F., Ciccotti, E., De Leo, G.A., Zane, L., 2011a. Genetic patchiness in European eel adults evidenced by 
molecular genetics and population dynamics modelling. Molecular Phylogenetics and Evolution 58, 198-206.

Pujolar, J.M., Bevacqua, D., Capoccioni, F., Ciccotti, E., De Leo, G.A., Zane, L., 2011b. No apparent genetic bottleneck in the demographically declining European eel using molecular genetic and forward-time simulations. Conservation Genetics $12,813-825$.

Pujolar, J.M., Marino, I.A.M., Milan, M., Coppe, A., Maes, G.E., Capoccioni, F., Ciccotti, E., Bervoets, L., Covaci, A., Belpaire, C., Cramb, G., Patarnello, T., Bargelloni, L., Bortoluzzi, S., Zane, L., 2012. Surviving in a toxic world: transcriptomics and gene expression profiling in response to environmental pollution in the critically endangered European eel. BMC Genomics 13, 507.

Quiros, L., Pina, B., Solee, M., Blasco, J., Lopez, M.A., Riva, M.C., Barcelo, D., Raldua, D., 2007. Environmental monitoring by gene expression biomarkers in Barbus graellsii: laboratory and field studies. Chemosphere $67,1144-1154$

Robinet, T.T., Feunteun, E., 2002. Sublethal effects of exposure to chemical compounds: a cause for the decline in Atlantic eels? Ecotoxicology 11, 265-277.

Roosens, L., Geeraerts, C., Belpaire, C., Van Pelt, I., Neels, H., Covaci, A., 2010. Spatial variations in the levels and isomeric patterns of PBDEs and HBCDs in the European eel in Flanders. Environment International 36, 415-423.

Saeed, A.I., et al., 2003. TM4: a free, open-source system for microarray data management and analysis. Biotechniques 34, 374-378.

Schuetz, E.G., Brimer, C., Schuetz, J.D., 1998. Environmental xenobiotics and the antihormones cyproterone acetate and spironolactone use the nuclear hormone pregnenolone $\mathrm{x}$ receptor to activate the CYP3A23 hormone response element. Molecular Pharmacology 54, 1113-1117.

Storey, J.D., 2002. A direct approach to false discovery rates. Journal of the Royal Statistical Society: Series B 64, 479-498.
Thomas, M.A., Klaper, R., 2004. Genomics in the ecological toolbox. Trends in Ecology \& Evolution 19, 439-445.

Thomas, R.S., Rank, D.R., Zastrow, S.G.P.G.M., Hayes, K.R., Pande, K., Glover, E. Silander, T., Craven, M.W., Reddy, J.K., Jovanovich, S.B., Bradfield, C.A., 2001. Identification of toxicologically predictive gene sets using cDNA microarrays. Molecular Pharmacology 60, 1189-1194.

Travers, S.E., Smith, M.D., Bai, J., Hulbert, S.H., Leach, J.E., Schnable, P.S., Knapp, A.K, Milliken, G.A., Fray, P.A., Saleh, A., Garrett, K.A., 2007. Ecological genomics: making the leap from model systems in the lab to native populations in the field. Frontiers in Ecology and the Environment 5, 19-24.

Tseng, H., Hseu, T., Buhler, D.R., Wang, W., Hu, C., 2005. Constitutive and xenobioticsinduced expression of a novel CYP3A gene from zebrafish larva. Toxicology and Applied Pharmacology 205, 247-258.

Tusher, V.G., Tibshirani, R., Chu, G., 2001. Significance analysis of microarrays applied to the ionizing radiation response. Proceedings of the National Academy of Sciences of the United States of America 98, 5116-5121.

Ungerer, M.C., Johnson, L.C., Herman, M.A., 2008. Ecological genomics: understanding gene and genome function in the natural environment. Heredity 100 , $178-183$.

van den Thillart, G., Rankin, J.C., Dufour, S., 2009. Spawning Migration of the European eel: Reproduction Index, a Useful Tool for Conservation Management Springer, Dordecht, The Netherlands.

Van der Oost, R., Beyer, J., Vermeulen, N.P.E., 2003. Fish bioaccumulation and biomarkers in environmental risk assessment: a review. Environmental Toxicology and Pharmacology 13, 57-149.

Vandersteen, W., 2011. Detecting gene expression profiles associated with environmental stressors within an ecological context. Molecular Ecology 20 $1322-1323$ 